\title{
PENGARUH PENGGANTIAN SEBAGIAN JAGUNG DENGAN SILASE KULIT PISANG KEPOK (Musa paradisiaca formatypica) DALAM RANSUM TERHADAP PERFORMANS AYAM BROILER
}

\author{
Alfian Y. Nuraga, Florencia N. Sompie*, Youdhie H. S. Kowel, Mursye N. Regar
}

Fakultas Peternakan Universitas Sam Ratulangi Manado, 95115

\begin{abstract}
ABSTRAK
Penelitian ini dilakukan untuk mengetahui sejauh mana pengaruh pergantian sebagian jagung dengan silase kulit pisang kepok dalam ransum yang diukur melalui performans ayam broiler. Ternak yang digunakan dalam penelitian ini, yaitu 60 ekor ayam broiler unsexed Strain Cobb umur 1 hari. Rancangan penelitian yang digunakan adalah rancangan acak lengkap (RAL) yang terdiri dari 4 perlakuan dan 5 ulangan. Susunan perlakuan sebagian berikut: $\mathrm{R}_{0}=50 \%$ jagung, $0 \%$ silase kulit pisang kepok, $\mathrm{R}_{1}=$ $42,5 \%$ jagung, $7,5 \%$ silase kulit pisang kepok, $\mathrm{R}_{2}=35 \%$ jagung, $15 \%$ silase kulit pisang kepok, $\mathrm{R}_{3}=27,5 \%$ jagung, $22,5 \%$ silase kulit pisang kepok. Hasil penelitian menunjukan bahwa perlakuan memberikan pengaruh yang berbeda sangat nyata $(\mathrm{P}<0,01)$ terhadap konsumsi ransum, berbeda nyata $(\mathrm{P}<0,05) \quad$ terhadap pertambahan bobot badan dan konversi ransum. Berdasarkan hasil penelitian maka disimpulkan bahwa silase kulit pisang kepok dapat mengantikan jagung sampai $45 \%$ atau digunakan sampai $22,5 \%$ dalam ransum ayam broiler.
\end{abstract}

Kata kunci: Silase Kulit Pisang kepok, Broiler, Performans.

*Korespondensi (corresponding Author)

Email: nerysompie@yahoo.co.id
ABSTRACT

UTILIZATION OF ENSILAGE KEPOK BANANA PEELS REPLACING PART OF CORN IN THE DIET ON BROILER PERFORMANCE. The study was conducted to determine the extent of the effect of partial replacement of corn with ensilage kepok banana peels in the ration on broiler performance. This study uses a 60 head broiler unsexed strains Cobb age of 1 day. The study design used completely randomized design (CRD), which consists of 4 treatments and 5 replications. The composition of experimental treatments in part the following: $\mathrm{R}_{0}=50 \%$ of yellow corn and $0 \% ; \mathrm{R}_{1}=42.5 \%$ of yellow corn and $7.5 \%$; $\mathrm{R}_{2}=35 \%$ of yellow corn and $15 \%$ ensilage kapok banana peels ; $\mathrm{R}_{3}=27.5 \%$ of yellow corn and $22.5 \%$ ensilage kepok banana peels. The results showed that the treatment effect highly significant $(\mathrm{P}<0.01)$ on feed consumption, significantly different $(\mathrm{P}<0,05)$ on body weight gain and feed conversion. Based on the results it was concluded that the ensilage kapok banana peels can replace yellow corn up to $45 \%$ or used in the ration of broiler chickens up $22.5 \%$.

Keywords:,Broiler, ensilage kepok banana peels, Performance.

\section{PENDAHULUAN}

Ayam broiler merupakan ternak penghasil daging yang pertumbuhannya 
cepat. Keunggulan ayam broiler lainnya, yaitu konversi ransum kecil, siap dipotong pada usia muda dan menghasilkan daging berserat lunak. Keunggulan-keunggulan tersebut, harus didukung dengan penyediaan makanan yang sesuai kebutuhan ayam broiler. Peningkatan produktivitas ayam broiler merupakan salah satu usaha untuk mempercepat penyediaan sumber protein hewani bagi masyarakat.

Keberhasilan suatu usaha peternakan sangat dipengaruhi oleh ransum yang digunakan dan dimanfaatkan oleh ternak. Salah satu hal yang mempengaruhi performans ayam broiler, yaitu ransum yang dikonsumsi. Jagung merupakan bahan ransum sumber energi yang paling banyak digunakan dalam penyusun ransum broiler, namun harganya seringkali mahal karena dikonsumsi juga oleh manusia. Salah satu cara yang dapat dilakukan guna mengatasi masalah tersebut, yaitu dengan memanfaatkan bahan pakan alternatif dari sumber daya lokal yang tersedia dan tidak digunakan lagi, namun kandungan nutrisinya terutama energi setara dengan jagung.

Kulit pisang kepok (Musa paradisiaca formatypica) merupakan bagian dari buah pisang yang dibuang, yang sebenarnya dapat dimanfaatkan sebagai bahan alternatif penyusun ransum. Indonesia merupakan salah satu Negara penghasil pisang terbesar, karena tumbuhan ini tumbuh dengan baik di daerah tropis. Tingkat konsumsi masyarakat Indonesia terhadap pisang juga cukup tinggi, sehingga mudah mendapatkan kulit pisang dalam jumlah yang besar.

Kandungan gizi kulit pisang cukup lengkap, seperti karbohidrat, lemak, protein, kalsium, fosfor, zat besi, vitamin B, vitamin C, dan air. Menurut Marhaeniyanto (2009) kulit pisang yang hampir masak mengandung bahan kering 92,38\%, serat kasar $11,10 \%$, lemak kasar $14,20 \%$, protein kasar 6,61\%, abu 14,27\%, kalsium 0,38\%, dan fosfor $0,29 \%$, sedangkan gross energinya $4.692 \mathrm{Kkal} / \mathrm{kg}$. Hasil penelitian menunjukan kadar air kulit pisang kepok sebesar 16,69\% (Sheryl dan Cahyaningrum, 2014). Kulit pisang mengandung zat anti nutrisi, yaitu tanin 4,97\%. Tanin memberikan pengaruh kurang menguntungkan terhadap pemanfaatan zat -zat makanan (Mahopatra et al., 2010), sehingga dibutuhkan penanganan atau sentuhan teknologi untuk menghilangkan atau menurunkan pengaruh kurang menguntungkan dari tanin.

Pembuatan silase merupakan salah satu cara untuk meningkatkan kualitas kulit pisang kepok dan mengurangi zat anti nutrisi yang terkandung di dalamnya. Silase adalah hasil fermentasi dari bahan ransum yang berkadar air tinggi dan dalam keadaan kedap udara (anaerob) oleh bakteri asam 
laktat. Pada susunan anaerob tersebut akan mempercepat pertumbuhan bakteri anaerob untuk membentuk asam laktat (Mugiawati, 2013). Asam laktat yang terkandung dalam silase yang dikonsumsi digunakan oleh ternak sebagai sumber energi dan juga sebagai probiotik (Widyastuti, 2008). Produk hasil bioproses seperti silase dari bahan tunggal dengan kandungan serat kasar tinggi umumnya masih memiliki nilai nutrisi relatif belum mencukupi kebutuhan zat makanan produksi broiler yang maksimal, sehingga dalam proses fermentasinya harus dilakukan pengayaan zat makanan untuk meningkatkan nilai manfaat (Dhalika et al., 2011). Produk hasil bioproses seperti silase dari bahan tunggal dengan kandungan serat kasar tinggi umumnya masih memiliki nilai nutrisi yang relatif rendah belum mencukupi kebutuhan zat makanan untuk produksi broiler yang maksimal.

Proses ensilasi merupakan cara pengayaan (enrichment) bahan makanan untuk meningkatkan nilai manfaatnya. Pembuatan silase kulit pisang kepok merupakan salah satu cara untuk menjaga stabilitas dan mutu bahan selama penyimpanan. Proses pembuatan silase kulit pisang diawali dengan pencampuran/penambahan molases sebagai permulaan ensilasi, untuk mempercepat proses fermentasi serta meningkatkan kualitas fisik dan kimia dari kulit pisang kepok. Molases merupakan sumber energi yang esensial dalam proses ensilasi. Molases memiliki keterbatasan pemberian dalam ransum ternak karena kadar kaliumnya yang tinggi, sehingga bisa menyebabkan diare jika dikonsumsi terlalu banyak oleh ternak. Penelitian ini telah dilaksanakan untuk melihat pengaruh penggantian sebagian jagung dengan silase kulit pisang kepok dalam ransum terhadap performans broiler.

\section{MATERI DAN METODE PENELITIAN}

Ternak yang digunakan, yaitu 60 ekor broiler unsexed strain Cobb umur 1 hari, dan dipelihara sampai umur 6 minggu. Kandang yang digunakan, yaitu kandang batere sebanyak 20 unit. Setiap unit berukuran $20 \times 30 \times 30 \mathrm{~cm}$ sebanyak 20 unit kandang dilengkapi dengan lampu pijar 60 watt, serta tempat makan dan minum yang terbuat dari plastik. Perlengkapan lain yang digunakan, yaitu timbangan, wadah untuk mencampur ransum perlakuan, koran bekas, ember, alat tulis untuk mencata data bobot ayam, ransum, dan lain-lain.

Ransum yang digunakan dalam penelitian ini terdiri dari jagung kuning, bungkil kelapa, tepung ikan, tepung 
Tabel 1. Komposisi Zat-Zat Makanan dan Energi Metabolis Bahan Pakan Penyusun Ransum Percobaan.

\begin{tabular}{|c|c|c|c|c|c|c|}
\hline Bahan Makanan & $\begin{array}{l}\text { Protein } \\
(\%)\end{array}$ & $\begin{array}{c}\text { Serat } \\
\text { Kasar }(\%)\end{array}$ & $\begin{array}{c}\text { Lemak } \\
(\%)\end{array}$ & $\begin{array}{c}\mathrm{Ca} \\
(\%)\end{array}$ & $\begin{array}{c}\mathrm{P} \\
(\%)\end{array}$ & $\begin{array}{c}\text { Energi Metabolis } \\
(\mathrm{Kkal} / \mathrm{kg})\end{array}$ \\
\hline Jagung * & 8,01 & 3,45 & 7,71 & 0,17 & 0,70 & 2865,75 \\
\hline Tepung SKPK * & 10,76 & 7,58 & 7,07 & 0,52 & 0,39 & 3360,75 \\
\hline Tepung Ikan * & 63,6 & 0,5 & 9,3 & 5,81 & 3,23 & 2830 \\
\hline Tepung Kedelai * & 42,02 & 6,40 & 13,22 & 0,21 & 0,65 & 3603 \\
\hline Bungkil Kelapa * & 20,55 & 15,88 & 15,07 & 0,21 & 0,49 & 3724,5 \\
\hline Dedak * & 8,36 & 16,53 & 6,58 & 0,18 & 0,84 & 2564,25 \\
\hline Top Mix & - & - & - & 5,38 & 1,44 & - \\
\hline Minyak & - & - & 100 & - & - & 8812 \\
\hline
\end{tabular}

Keterangan: * Hasil Analisis Laboratorium Ruminansia dan Kimia Makanan Fakultas Peternakan Universitas Padjajaran, Bandung..

- SKPK (silase kulit pisang kepok)

Tabel 2. Susunan Ransum Perlakuan Serta Komposisi Zat-zat Makanan dan Energi Metabolis

\begin{tabular}{lcccc}
\hline \multicolumn{1}{c}{ Bahan Ransum } & $\mathrm{R}_{0}$ & $\mathrm{R}_{1}$ & $\mathrm{R}_{2}$ & $\mathrm{R}_{3}$ \\
\hline Jagung (\%) & 50 & 42,5 & 35 & 27,5 \\
Tepung SKPK (\%) & 0 & 7,5 & 15 & 22,5 \\
Tepung Kedelai (\%) & 13 & 13 & 13 & 13 \\
Bungkil Kelapa (\%) & 12 & 12 & 12 & 12 \\
Tepung Ikan (\%) & 14 & 14 & 14 & 14 \\
Dedak (\%) & 9,5 & 9,5 & 9,5 & 9,5 \\
Top Mix (\%) & 0,5 & 0,5 & 0,5 & 0,5 \\
Minyak (\%) & 1 & 1 & 1 & 1 \\
\hline Total & 100 & 100 & 100 & 100 \\
\hline \multicolumn{1}{c}{ Zat - Zat Makanan * } & \multicolumn{3}{c}{} \\
\hline Protein (\%) & 21,63 & 21,84 & 22,05 & 22,25 \\
Serat Kasar (\%) & 6,10 & 6,41 & 6,72 & 7,03 \\
Lemak (\%) & 9,30 & 9,25 & 9,21 & 9,16 \\
Ca (\%) & 0,99 & 1,02 & 1,05 & 1,07 \\
P $(\%)$ & 1,03 & 1,01 & 0,98 & 0,96 \\
Energi Metabolis (Kkal/kg) & 3076,12 & 3113,24 & 3150,37 & 3187,50 \\
\hline Keterangan: Dihitung bedasar
\end{tabular}

Keterangan: * Dihitung bedasarkan Tabel 1

kedelai, dedak halus, silase kulit pisang kepok (SKPK), dan top mix. Limbah kulit pisang kepok yang digunakan diperoleh dari rumah makan di dekat kampus Unsrat. Komposisi serta zat-zat makanan dan energy metabolis bahan pakan penyusun ransum dapat dilihat pada Tabel 1. Susunan ransum perlakuan serta komposisi zat-zat makanan dan energi metabolis tercantum pada Tabel 2.

Proses pembuatan silase kulit pisang kepok diuraikan sebagai berikut: 
Kulit pisang kepok segar dipotong - potong dengan ukuran sekitar 2-3 cm. Pemotongan dilakukan agar mudah dimasukkan ke dalam silo dan mengurangi ruang udara di dalam silo serta memudahkan pemadatan. Setelah dipotong-potong dicuci bersih dengan air mengalir, ditiriskan, ditimbang berat awal dan diangin-anginkan selama 34 hari (tergantung cuaca). Setelah itu pemberian molases sebanyak $6 \%$ disesuaikan dengan berat akhir kulit pisang. Sesudah diangin - anginkan pemberian molases dituang secara merata setiap lapisannya, demikian seterusnya sampai kulit pisang tercampur rata dengan molases. Kulit pisang dimasukkan ke dalam plastik bening (silo) ukuran $80 \mathrm{~cm} \mathrm{x} 100 \mathrm{~cm}$, kemudian dilakukan pengukuran awal untuk suhu dan $\mathrm{pH}$. Setelah itu di vakum sampai terlihat padat, diikat dengan karet, dilapisi lagi dengan plastik hitam (divakum dan diikat) selanjutnya ditempatkan di dalam ruang tertutup yang tidak terkena sinar matahari dan air hujan secara langsung. Proses pembuatan silase (ensilase) kulit pisang berlangsung selama 21 hari. Pada hari ke 22 silo dibuka, diukur kembali suhu dan $\mathrm{pH}$ dan diambil secara bertahap kemudian langsung dimasukkan ke dalam oven selama 3 hari atau dijemur di bawah sinar matahari langsung sampai kering. Kulit pisang kering, digiling sampai halus kemudian dianalisis. Selanjutnya dicampur dalam ransum broiler sesuai dengan level pemberian pada setiap perlakuan. Penelitian ini merupakan penelitian eksperimental dengan menggunakan Rancangan Acak Lengkap (Steel and Torrie, 1995) yang terdiri dari 4 perlakuan dan 5 ulangan, dengan susunan perlakuan sebagai berikut :

$\mathrm{R}_{0}=50 \%$ jagung, dan $0 \%$ Silase kulit pisang kepok

$\mathrm{R}_{1}=42,5 \%$ jagung, dan $7,5 \%$ Silase kulit pisang kepok

$\mathrm{R}_{2}=35 \%$ jagung, dan $15 \%$ Silase kulit pisang kepok

$\mathrm{R}_{3}=27,5 \%$ jagung, dan $22,5 \%$ Silase kulit pisang kepok

Uji lanjut dilakukan untuk pengaruh perlakuan yang berbeda nyata dengan menggunakan uji Beda Nyata Jujur (BNJ). Penempatan ternak dan perlakuan di setiap unit kandang dilakukan secara acak. Yang diukur meliputi konsumsi, pertumbuhan bobot badan, dan konversi :

1. Konsumsi ransum (gram): diperoleh dari selisih antara jumlah ransum yang diberikan dengan ransum sisa setiap harinya.

2. Pertumbuhan bobot badan (gram) : diperoleh dari selisih penimbangan antara bobot badan akhir dengan bobot badan awal penimbangan.

3. Konversi ransum : perbandingan antara konsumsi ransum rata-rata per ekor per hari dengan pertambahan bobot badan rata-rata 
per ekor per hari selama periode peneliti.

\section{HASIL DAN PEMBAHASAN}

Hasil penelitian pengaruh penggantian sebagian jagung dengan silase kulit pisang kepok (musa paradisiaca formatypica) dalam ransum terhadap performans ayam broiler dapat dilihat pada Tabel 3.

\section{Pengaruh Perlakuan terhadap Konsumsi Ransum}

Rataan konsumsi ransum per ekor per hari selama penelitian dapat dilihat pada Tabel 3. Pada Tabel tersebut terlihat bahwa nilai rataan konsumsi ransum berkisar antara 79,46 - 86,82 g/ekor/hari. Rataan konsumsi ransum tertinggi terdapat pada perlakuan tanpa penggunaan SKPK $\left(\mathrm{R}_{0}\right)$ dan terendah pada ransum yang menggunakan SKPK sebesar 22,5\% ( $\left.\mathrm{R}_{3}\right)$. Kisaran rataan konsumsi ransum pada penelian ini masih berada pada kisaran seperti yang dinyatakan Wahyu (2004), bahwa konsumsi ransum broiler $0-6$ minggu yaitu $77-135$ g/ekor/hari.

Berdasarkan hasil analisis keragaman, menunjukkan bahwa penggantian jagung dengan SKPK dalam ransum memberikan pengaruh yang berbeda nyata $(\mathrm{P}<0,05)$ terhadap konsumsi ransum. Hasil uji BNJ, menunjukkan bahwa perlakuan $\mathrm{R}_{0}$ berbeda nyata lebih tinggi $(\mathrm{P}<0,05)$ dibandingkan dengan perlakuan $R_{3}$, demikian pula dengan perlakuan $R_{1}$ berbeda nyata lebih tinggi $(\mathrm{P}<0,05)$ dengan perlakuan $\mathrm{R}_{3}$. Perlakuan $\mathrm{R}_{2}$ berbeda tidak nyata $(\mathrm{P}>0,05)$ dengan perlakuan $\mathrm{R}_{0}, \mathrm{R}_{1}$, dan $\mathrm{R}_{3}$.

Konsumsi ransum dipengaruhi oleh beberapa faktor, yaitu rasa, bau, dan warna ransum (Scott et al., 1982). Ransum perlakuan dalam penelitian ini, warnanya cenderung lebih gelap dibandingkan dengan ransum kontrol. Hal ini disebabkan adanya pemberian SKPK dalam ransum, yang warnanya lebih gelap. Hal ini diduga mempengaruhi konsumsi ransum. Pada penelitian ini, kandungan energi meningkat seiring meningkatnya penggunaan silase kulit pisang kepok dalam ransum, yang mengakibatkan konsumsi ransum menurun.

\section{Pengaruh Perlakuan terhadap Pertambahan Bobot Badan}

Rataan pertambahan bobot badan per ekor per hari selama penelitian dapat dilihat pada Tabel 3. Pada tabel tersebut menunjukkan bahwa nilai rataan pertambahan bobot badan broiler berkisar antara 29,73 - 41,31 g/ekor/hari. Bobot badan tertinggi dihasilkan oleh kelompok 
Tabel 3. Rataan Konsumsi ransum, Pertambahan Bobot Badan, Konversi Ransum Broiler Dari Masing-Masing Perlakuan

\begin{tabular}{|c|c|c|c|c|}
\hline \multirow{2}{*}{$\begin{array}{c}\text { Variabel } \\
\text { (g/ekor/hari) }\end{array}$} & \multicolumn{4}{|c|}{ Perlakuan } \\
\hline & R0 & R1 & R2 & R3 \\
\hline Konsumsi ransum & $86,82^{a}$ & $85,09^{\mathrm{a}}$ & $83,05^{a b}$ & $79,46^{b}$ \\
\hline Pertambahan Bobot Badan & $41,31^{\mathrm{a}}$ & $36,53^{a b}$ & $33,21 \mathrm{bc}$ & $29,73^{c}$ \\
\hline Konversi Ransum & $2,11^{\mathrm{a}}$ & $2,35^{\mathrm{ab}}$ & $2,54^{\mathrm{b}}$ & $2,68^{\mathrm{b}}$ \\
\hline
\end{tabular}

broiler yang mendapatkan ransum tanpa menggunakan silase kulit pisang kepok $\left(\mathrm{R}_{0}\right)$ dan terendah pada ransum yang menggunakan silase kulit pisang kepok sebesar 22,5\% $\left(\mathrm{R}_{3}\right)$. Hasil penelitian ini lebih tinggi dari hasil penelitian Koni (2013) yang memperoleh hasil pertambahan bobot badan broiler hanya berkisar antara 23,81 - 33,35 g/ekor/hari. Berdasarkan hasil analisis keragaman, menunjukkan bahwa penggantian jagung dengan SKPK dalam ransum memberikan pengaruh berbeda nyata $(\mathrm{P}<0,05)$ terhadap pertambahan bobot badan broiler. Hasil uji BNJ, menunjukkan bahwa pertambahan bobot badan perlakuan $\mathrm{R}_{0}$ nyata $(\mathrm{P}<0,05)$ lebih tinggi dibanding perlakuan $R_{2}$ dan $R_{3}$, tetapi berbeda tidak nyata $(\mathrm{P}>0,05)$ dengan perlakuan $\mathrm{R}_{1}$. Perlakuan $\mathrm{R}_{1}$ berbeda nyata $(\mathrm{P}<0,05)$ lebih tinggi dibandingkan dengan perlakuan $R_{3}$, tetapi berbeda tidak nyata ( $\mathrm{P}>0,05)$ dengan perlakuan $\mathrm{R}_{2}$. Perlakuan $\mathrm{R}_{2}$ berbeda tidak nyata $(\mathrm{P}>0,05)$ dengan perlakuan $R_{1}$ dan $R_{3}$. Hasil yang didapat dalam penelitian ini sejalan dengan hasil yang diperoleh pada konsumsi ransum.

Penggunaan silase kulit pisang kepok nyata menurunkan pertambahan bobot badan broiler, terutama pada perlakuan $\mathrm{R}_{3}(22,5 \%$ silase kulit pisang kepok). Semakin tinggi penggunaan silase kulit pisang kepok maka pertambahan bobot badan makin menurun. Hasil penelitian ini sejalan dengan penelitian Udjianto et al. (2005), yang melaporkan bahwa terjadi penurunan bobot badan dengan meningkatnya penggunaan kulit pisang yang difermentasi dengan probiotik. Hal ini diduga karena penggunaan silase kulit pisang kepok yang semakin tinggi pada setiap perlakuan, maka terjadi peningkatan kandungan energi dalam ransum (Tabel 2). Kandungan energi yang tinggi dalam ransum, menyebabkan penurunan konsumsi. Broiler akan berhenti makan ketika kebutuhan energi telah terpenuhi. Menurut Maryuni dan Wibowo (2005), bahwa kandungan energi ransum menentukan besarnya konsumsi 
ransum karena broiler merupakan ternak yang mengkonsumsi ransum untuk memenuhi kebutuhan energi.

\section{Pengaruh Perlakuan terhadap Konversi Ransum}

Data rataan konversi ransum dalam penelitian ini dapat dilihat pada Tabel 3. Pada Tabel 3 tersebut terlihat bahwa rataan konversi ransum berkisar antara 2,11 2,68. Rataan konversi ransum terendah diperoleh pada perlakuan $\left(\mathrm{R}_{0}\right)$, dan tertinggi pada perlakuan $\left(\mathrm{R}_{3}\right)$. Nilai konversi ransum dalam penelitian ini lebih rendah dibandingkan dengan penelitian yang dilaporkan Djapili et al. (2016), yaitu berkisar antara 2,62 - 3,09 g/ekor/hari. Nilai konversi ransum yang direkomendasikan oleh Kartasudjana dan Suprijatna (2006) untuk broiler umur 6 minggu adalah 2,35 g/ekor/hari.

Berdasarkan hasil analisis keragaman, menunjukkan bahwa penggantian jagung dengan SKPK dalam ransum memberikan pengaruh yang berbeda nyata $(\mathrm{P}<0,05)$ terhadap konversi ransum. Hasil uji BNJ, menunjukkan bahwa konversi ransum antara perlakuan $\mathrm{R}_{0}$, dan $\mathrm{R}_{1}$, berbeda tidak nyata $(\mathrm{P}>0,05)$, demikian juga antara perlakuan $\mathrm{R}_{1}, \mathrm{R}_{2}$ dan $\mathrm{R}_{3}$. Perlakuan $\mathrm{R}_{0}$ berbeda nyata $(\mathrm{P}<0,05)$ lebih rendah dibandingkan perlakuan $\mathrm{R}_{2}$ dan $\mathrm{R}_{3}$. Suprijatna et al. (2005) menyatakan bahwa konversi ransum sangat dipengaruhi oleh konsumsi dan pertambahan bobot badan. Angka konversi ransum yang rendah berarti jumlah pakan yang dikonsumsi untuk menghasilkan satu kilogram daging semakin sedikit. Semakin rendahnya angka konversi ransum maka menunjukkan ternak tersebut semakin efesien dalam penggunaan ransum yang diberikan. Hal ini sejalan dengan pendapat Kartasudjana dan Suprijatna (2006) yang menyatakan bahwa konversi ransum sangat dipengaruh oleh konsumsi dan pertambahan bobot badan. Komposisi serta zat-zat makanan dan energi metabolis bahan pakan penyusun.

\section{KESIMPULAN}

Berdasarkan hasil penelitian maka disimpulkan bahwa silase kulit pisang kepok dapat mengantikan jagung sampai $45 \%$ atau digunakan sampai $22,5 \%$ dalam ransum ayam broiler.

\section{DAFTAR PUSTAKA}

Djapili, D., F. Wolayan, I. Untu dan H. Liwe, 2016. Pengaruh penggantian sebagian jagung dengan tepung kulit pisang raja (Musa Paradisiaca) dalam ransum terhadap performans broiler. Jurnal Zootek. Vol. 36 (1) : $158-166$.

Dhalika, T., A. Budiaman, B. Ayuningsi dan Mansyur. 2011. Nilai nutrisi batang pisang dari produk bioproses (ensilage) sebagai ransum lengkap. 
Jurnal Ilmu Peternakan Ternak Vol. $11(1): 17-23$.

Kartasudjana, R. dan E. Suprijatna. 2006. Manajemen Ternak Unggas. Cetakan Pertama. Penebar Swadaya. Jakarta.

Koni, T.N.I. 2013. Pengaruh pemanfaatan kulit pisang yang difermentasi terhadap karkas broiler. Jurnal Peternakan Politeknik Pertanian Negeri Kupang Vol. 18 (2) : 153 157.

Mahopatra, Debabandya, Mishra, Sabyasachi, Sutar, dan Namrata. 2010. Banana and its by - product utilization; an overview. Jurnal of Scientific and Industrial Recearch Vol. 69 (5) : 323 - 329.

Marhaeniyanto. 2009. Pemanfaatan Limbah Pisang Sebagai Pengembangan Ternak. Skripsi. Universitas Tribhuwana Tunggadewi. Malang.

Maryuni, S. S. dan C. H. Wibowo. 2005. Pengaruh kandungan lisin dan energi metabolis dalam ransum yang mengandung ubi kayu fermentasi terhadap konsumsi ransum dan lemak ayam broiler. Jurnal Indo Trop Anim Agric. Vol. 30 (1) : 26 33.

Mugiawati, R. E. 2013. Kadar air dan pH silase rumput gajah pada hari ke-21 dengan penembahan jenis aditif dan bakteri asam laktat. Jurnal Ternak Ilmiah. Vol. 1 (1) : 201 - 207.
Scott, M. L., M. C. Nesheim and R. J. Young. 1982. Nutrition of the Chicken. M. L. Scott and Assciates, Itaca, New York.

Sheryl, A., dan S.E. Cahyaningrum. 2014. Aktivitas kulit pisang kepok (Musa acuminate L.) dengan $\mathrm{H}_{2} \mathrm{SO}_{4}$ dan pulikasinya sebagai adsorben ion logam $\mathrm{Cr}(\mathrm{Vi})$. UNESA Jounal of Chemistry Vol. 3 (1): 22-25

Suprijatna, E., U. Atmomarsono, and R. Kartasujana. 2005. Ilmu Dasar Ternak Unggas. Penerbit Penebar Swadaya. Jakarta.

Steel, R. G. D. and J. H. Torrie 1995. Prinsip dan Prosedur Statistika: Suatu Pendekatan Biometrik. Terjemahan B. Sumantri. Gramedia Pustaka Utama, Jakarta.

Udjianto, A., E. Rostianti, D.R. Purnama. 2005. Pengaruh pemberian limbah kulit pisang fermentasi terhadap pertumbuhan ayam pedanging dan analisis usaha. Prosiding Teknis Nasional Tenaga Fungsional Pertanian, Bogor. 76-81.

Wahyu, J. 2004. Ilmu Nutrisi Unggas. Cetakan Kelima. Gadjah Mada University Press. Yogyakarta.

Widyastuti, Y. 2008. Fermentasi silase dan manfaat probiotik silase bagi ruminansia. Jurnal Media Peternakan. Vol. 31 (3): 225 - 232. 